\title{
A rare manifestation of chronic lymphocytic leukaemia - leukaemia cutis treated with ibrutinib
}

\author{
Białaczka skóry w przebiegu przewlekłej białaczki limfocyłowej leczona \\ ibrutynibem
}

\author{
Małgorzata Osmola', Beata Gierej², Anna Waszczuk-Gajda', Agata Dominika Kłosowicz³, \\ Marta Hałaburda-Rola ${ }^{4}$, Wiesław Wikłor Jędrzejczak', Grzegorz Władysław Basak', \\ Bogna Ziarkiewicz-Wróblewska²
}

\begin{abstract}
'Department of Haematology, Oncology, and Internal Diseases, University Clinical Centre, Medical University of Warsaw 2Department of Pathomorphology, Medical University of Warsaw

${ }^{3}$ Department of Dermatology, University Hospital, Medical University of Cracow

${ }^{4}$ Department of Radiology, University Clinical Centre, Medical University of Warsaw
\end{abstract}

\section{Abstract}

Skin infiltration by leukaemia (leukaemia cutis - LC) in chronic lymphocytic leukaemia (CLL) occurs in less than $5 \%$ of affected patients. It is significantly less common than skin cancers complicating the course of CLL, with an incidence of up to $20 \%$, and non-specific skin lesions. Therefore, it is crucial to perform additional diagnostic tests to establish the aetiology of skin lesions in CLL patients.

In this report, we present a case of a 60-year-old woman with CLL, in whom diffuse skin lesions were observed seven years after diagnosis, histologically confirmed as CLL infiltrates, and who responded well to treatment with ibrutinib.

Key words: chronic lymphocytic leukaemia, leukaemia cutis, ibrutinib.

\section{Streszczenie}

Naciek skóry przez białaczkę w przewlekłej białaczce limfocytowej (chronic lymphocytic leukaemia CLL) występuje u ok. 5\% pacjentów. Jest znacznie rzadziej obserwowany niż nowotwory skóry komplikujące przebieg CLL z częstością do $20 \%$ czy niespecyficzne zmiany skórne. Dlatego kluczowe jest przeprowadzenie diagnostyki zmian w celu ustalenia ich etiologii u pacjentów z CLL.

W pracy przedstawiono przypadek 60-letniej kobiety z CLL, u której 7 lat po ustaleniu rozpoznania zaobserwowano rozlane zmiany skórne, potwierdzone histologicznie jako naciek CLL, z dobrą odpowiedzią na leczenie ibrutynibem.

Słowa kluczowe: przewlekła białaczka limfocytowa, białaczka skóry, ibrutynib.

Address for correspondence:

Beata Gierej, MD, PhD, Department of Pathomorphology, Medical University of Warsaw, e-mail: beatagierej@wp.pl

\section{INTRODUCTION}

Chronic lymphocytic leukaemia (CLL) is the most common leukaemia in western countries with an incidence of $4.2: 100,000$ per year. The median age of diagnosis is 72 years with $10 \%$ of patients diagnosed under 55 years old [1]. Skin infiltration by leukaemia (leukaemia cutis - LC) [2] in CLL is rare and occurs in less than $5 \%$ of affected patients [3]. It is significantly less common than skin cancers com- plicating course of CLL with an incidence of up to $20 \%$ [4], and non-specific skin lesions. Therefore, it is crucial to perform additional diagnostic tests to establish the aetiology of the skin lesions in CLL patients.

In this report, we present a case of a 60-year-old woman with CLL, in whom diffuse skin lesions were observed seven years after diagnosis, histologically confirmed as CLL infiltrates, and who responded well to the treatment with ibrutinib. 


\section{CASE REPORT}

We present a case of a 60 -year-old female patient with CLL, diagnosed eight years earlier in 11/2011. The diagnosis was made according to standard criteria: the presence of monoclonal B-lymphocytes with characteristic phenotype in the peripheral blood, confirmed by flow cytometry. At the time of diagnosis, the disease was in stage II according to Rai [5] classification (peripheral blood lymphocytes $70 \times 10^{9} /$, peripheral lymphadenopathy, splenomegaly). There was no del(17p) on the cytogenetic examination [6]. The following treatment regimens were used over the years: from 1/2012 fludarabine and cyclophosphamide (FC), 1/2013 rituximab, fludarabine and cyclophosphamide (R-FC), and 11/2015 rituximab and bendamustine (R-B). In 4/2017, rising lymphocytosis with intra-abdominal lymphadenopathy (aorto-caval lymph nodes with a transverse dimension of $125 \mathrm{~mm}$ showed on computed tomography) was found. The patient was subsequently treated with six cycles of bendamustine (B).

Due to lack of response and suspicion of Richter's transformation, on 03/2018 a surgical biopsy of the left iliac lymph node was performed. The histopathological evaluation revealed infiltration of chronic lymphocytic leukaemia/small lymphocytic lymphoma (CLL/SLL) with large, merging proliferation centres and an increased mitotic index of up to $50-60 \%$, histologically aggressive form of the disease, characterised in WHO 2017 classification as an intermediate stage between the typical CLL/SLL and Richter syndrome. In repeated cytogenetic examination, there was no del(17p) and no mutation in TP53 gene in the molecular examination using the Sanger method [7].

Due to the aggressive form of CLL, three cycles of R-CHOP (rituximab, cyclophosphamide, doxorubicin, vincristine, prednisone) were introduced, (3/2018-6/2018). During the control visit in 6/2018, the patient reported the appearance of follicular lesions on the skin of the forearms and shins (Fig. 1). A performed skin biopsy revealed CLL infiltration (Fig. 2). Computed tomography (CT) revealed progression of lymphadenopathy (aorto-caval lymph nodes with a transverse dimension of $135 \mathrm{~mm}$ ), which corresponded to disease progression (PD) (Fig. 3A). Skin infiltrations with CLL might have indicated an aggressive, refractory disease. It was decided to initiate treatment with a targeted therapy with Bruton's tyrosine kinase inhibitor - ibrutinib. After eight months of treatment the patient achieved complete response with incomplete marrow recovery [8] (CRi), according to response criteria. The laboratory results were as follows: peripheral blood lymphocytes count $3.5 \mathrm{G} / \mathrm{l}$, neutrophil count $1.4 \mathrm{G} / \mathrm{l}$, haemoglobin concentration $14.1 \mathrm{~g} / \mathrm{dl}$, and platelet count $80 \mathrm{G} / 1$. Thrombocytopaenia was considered to be unrelated to CLL but related to drug toxicity. There was a spectacular response of lymphadenopathy, with the decrease of the intra-abdominal lymph nodes, aorto-caval to $11 \mathrm{~mm}$ in the transverse dimension (Fig. 3B).

\section{Skin lesions}

Diffuse papillary lesions and nodules on erythematous ground with central necrosis, with a particular intensity on the skin of the upper and lower limbs were observed (Fig. 1). Skin changes were accompanied by severe pruritus, and according to the patient's report, appeared suddenly. Due to the sudden appearance of non-specific skin lesions, a skin biopsy was taken for histopathological examination with immunohistochemistry (Fig. 3): in the dermis, mainly around the blood vessels and skin appendages, infiltrates composed mostly of reactive T lymphocytes $(\mathrm{CD} 3+, \mathrm{CD} 5+)$ were found, with small groups of small $\mathrm{B}$ cells with immunophenotype typical for CLL: CD79+, PAX5+, CD23+, CD5+, CD3-, but without CD20 expression, (prior to the examination, chemotherapy with anti-CD20 monoclonal antibody was used in the treatment). The skin lesions disappeared during ibrutinib therapy.

\section{Histopathology}

The microscopic presentation of leukaemia cutis can be very diverse. Cerroni et al. described three main histological patterns based on a series of 42 cases of patients with skin leukaemia in CLL [9]. They distinguished three main subtypes: with lymphocytic infiltration around the vessels and skin appendages - perivascular and periadnexal pattern, nodu-

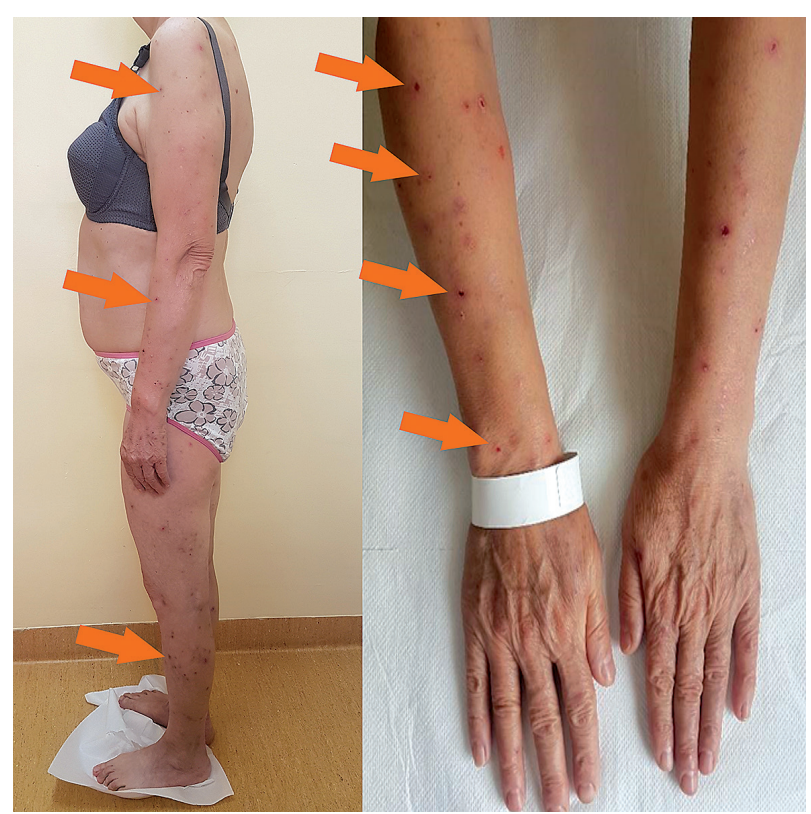

Fig. 1. Skin lesions with particular intensity on upper and lower limbs 

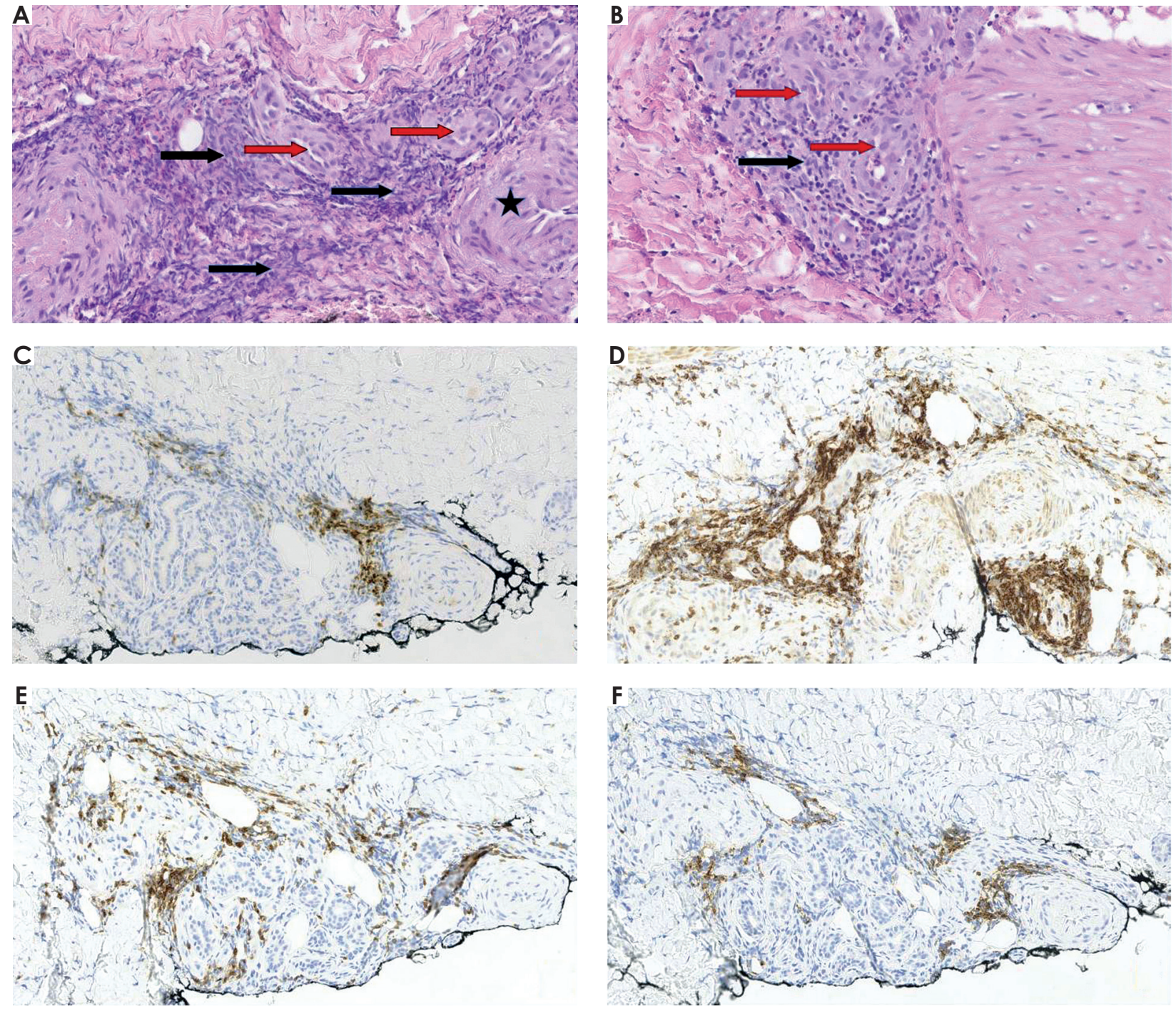

Fig. 2. Pathological examination and immunohistochemical staining. A, B) Infiltration of the dermis by small B lymphocytes (black arrows) with a tendency to localisation around blood vessels (asterix) and appendages (red arrow) of the skin. Haematoxylin and eosin staining, magnification 300x. C) Anti-PAX staining, magnification 200x. D) Anti-CD5 staining, magnification 200x E) Anti-CD3 staining, magnification 200x F) Anti-CD23 staining, magnification 200x

lar and diffuse pattern, and band-like pattern. Monoclonal B lymphocytes most often coexpress CD20, CD43, CD23, and CD5 molecules. In the presented case, the first subtype - perivascular and periadnexal - was present (Fig. 2).

\section{DISCUSSION}

The infiltration of skin by leukaemic cells is a rare manifestation of CLL with an unclear prognostic significance. In the described case, the changes occurred seven years after the diagnosis, after multiple lines of chemotherapy, with the latter being a R-CHOP regimen. Therefore, it can be concluded that the infiltrations of the skin indicated an aggressive and refractory disease.

The prognosis of LC in the course of CLL remains controversial. LC according to Raufi et al. did not worsen the prognosis of patients with CLL [10]. Other authors suggested worse prognosis in LC after the initiation of CLL systemic therapy and in Richter syndrome [11]. Colburn et al. suggested better prognosis in the appearance of LC [12]. In the latest study by Thiesen et al., it was shown that nearly half $(33 / 70)$ of LC lesions were located in close proximity to, or overlapped with, other skin lesions observed in non-melanoma skin tumours, precancerous states (actinic keratosis, Bowen's disease), and reactive inflammatory dermatoses (such as arthropod bites). The authors hypothesised that damage to the epidermal barrier may be a factor provoking the occurrence of LC [13].

In CLL patients, primary skin cancers are also common. In the study presented by Kleinstern et al., in which a group of 846 CLL patients were analysed, $20 \%$ developed skin cancer. Squamous cell carcinoma was the most common (59\%) [4]. Therefore, skin 

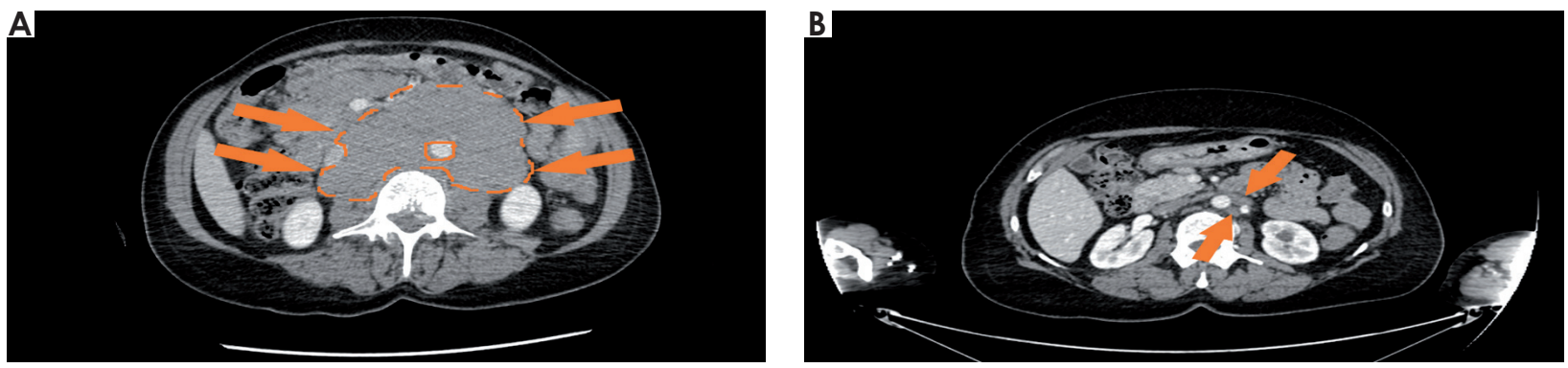

Fig. 3. Response to the treatment with ibrutinib in computed tomography. Aorto-caval lymph nodes with a transverse dimension of $135 \mathrm{~mm}$ at baseline (A) in September 2018 and after 8 months of ibrutinib (B), aorto-caval lymph nodes with a transverse dimension of $11 \mathrm{~mm}$ in June 2019. Aorto-caval lymph nodes are indicated with arrows

cancers should always be considered in the differential diagnosis of skin lesions in patients with CLL.

In the case of LC, various therapeutic options seem to be beneficial in symptomatic treatment. Authors of individual clinical case reports described therapeutic successes after using locoregional treatment [14-16]. In our case, however, systemic treatment of the underlying disease with ibrutinib was crucial.

Ibrutinib has demonstrated marked efficacy in CLL patients in clinical trials [17-19] and is approved by the US Food and Drug Administration for the therapy of CLL in any line of therapy. Its use has become a standard of care for relapsed CLL patients as well as for frontline high-risk patients with TP53 mutation and/or del(17p) [1, 8].

Usage of ibrutinib in CLL patients is relatively safe; the most serious adverse events include atrial fibrillation, bleeding, and infection [20]. The risk of complications during ibrutinib treatment increases with patient's age and coexisting comorbidities. In the presented case, the patient tolerated treatment very well; only temporary grade 2 thrombocytopaenia according to Common Terminology Criteria for Adverse Events (CTCAE) Version 5.0 was noted, which did not require dose modification.

In conclusion, ibrutinib is a highly effective therapy for patients with relapse-refractory CLL, and it shows efficacy in the treatment of leukaemia cutis in the course of CLL.

The authors declare no conflict of interest.

\section{REFERENCES}

1. Eichhorst B, Robak T, Montserrat E i wsp. Chronic lymphocytic leukaemia: ESMO Clinical Practice Guidelines for diagnosis, treatment and follow-up. Ann Oncol 2015; 26 (Suppl 5): v78-v84.

2. Siegel RS, Gartenhaus RB, Kuzel TM. Human T-cell lymphotropic-I-associated leukemia/lymphoma. Curr Treat Options Oncol 2001; 2: 291-300.

3. Hurt MA, Weedon D. Weedon's skin pathology. 3rd ed. Churchill Livingstone Elsevier, London 2010.
4. Kleinstern G, Rishi A, Achenbach SJ i wsp. Factors associated with non-melanoma skin cancer (NMSC) among chronic lymphocytic leukemia (CLL) patients. Blood 2017; 130 (Suppl 1).

5. Rai KR, Sawitsky A, Cronkite EP, Chanana AD, Levy RN, Pasternack BS. Clinical staging of chronic lymphocytic leukemia. Blood. 1975;46(2):219-234. Blood 2016; 128: 2109.

6. Pflug N, Bahlo J, Shanafelt TD i wsp. Development of a comprehensive prognostic index for patients with chronic lymphocytic leukemia. Blood 2014; 124: 49-62.

7. Catherwood M, Gonzalez D, Donaldson D i wsp. Relevance of TP53 for CLL diagnostics. J Clin Pathol 2019; 72: e343-e346.

8. Hallek M, Cheson BD, Catovsky D i wsp. iwCLL guidelines for diagnosis, indications for treatment, response assessment, and supportive management of CLL. Blood 2018; 131: 2745-2760.

9. Cerroni L, Zenahlik P, Höfler G i wsp. Specific cutaneous infiltrates of B-cell chronic lymphocytic leukemia: a clinicopathologic and prognostic study of 42 patients. Am J Surg Pathol 1996; 20: 1000-1010.

10. Raufi A, Alsharedi M, Khelfa Y i wsp. Leukemia cutis in a patient with chronic lymphocytic leukemia presenting as bilateral helical nodules. SAGE Open Med Case Reports 2016; 4: $2050313 X 1668362$.

11. Ratnam KV, Khor CJ, Su WP. Leukemia cutis. Dermatol Clin 1994; 12: 419-431.

12. Colburn DE, Welch MA, Giles FJ. Skin infiltration with chronic lymphocytic leukemia is consistent with a good prognosis. Hematology 2002; 7: 187-188.

13. Thiesen I, Wehkamp U, Bruggemann M, Ritgen M. Skin involvement by chronic lymphocytic leukemia is frequently associated with unrelated neoplastic or inflammatory cutaneous disease and is not indicative of general disease progression. $\mathrm{Br}$ J Dermatol 2019; 180: 227-228.

14. Bakst R, Yahalom J. Radiation therapy for leukemia cutis. Pract Radiat Oncol 2011; 1: 182-187.

15. Porter WM, Sidwell RU, Catovsky D i wsp. Cutaneous presentation of chronic lymphatic leukaemia and response to ultraviolet B phototherapy. Br J Dermatol 2001; 144: 1092-1094.

16. Sainsbury DC, Allison KP, Muir T. Electrochemotherapy treatment of a recalcitrant earlobe keloid scar with chronic lymphocytic leukaemia infiltration. J Plast Reconstr Aesthet Surg 2010; 63: e733-e736.

17. Brown JR, Hillmen P, O'Brien S i wsp. Extended follow-up and impact of high-risk prognostic factors from the phase 3 RESONATE study in patients with previously treated CLL/ SLL. Leukemia 2018; 32: 83-91.

18. Burger JA, Tedeschi A, Barr PM i wsp. RESONATE-2 Investigators. Ibrutinib as initial therapy for patients with chronic lymphocytic leukemia. N Engl J Med 2015; 373: 2425-2437.

19. Byrd JC, Brown JR, O'Brien S i wsp. RESONATE Investigators. Ibrutinib versus ofatumumab in previously treated chronic lymphoid leukemia. N Engl J Med 2014; 371: 213-223.

20. Maddocks KJ, Ruppert AS, Lozanski G i wsp. Etiology of ibrutinib therapy discontinuation and outcomes in patients with chronic lymphocytic leukemia. JAMA Oncol 2015; 1, 80-87. 